\title{
VITAMIN K2 IN OSTEOPOROSIS TREATMENT
}

\author{
CORINA ADELINA ZAH ${ }^{1}$, PAUL GRAMA ${ }^{2}$ \\ 1,2 “Iuliu Haţieganu” University of Medicine and Pharmacy, Cluj-Napoca
}

Keywords: osteoporosis, vitamin $k 2$, bone mineral density, osteocalcin, osteoporotic fractures

\begin{abstract}
Osteoporosis is represented by loss of bone mass with consequent bone fragility and increased risk of fractures. Current treatment options include several classes of drugs and adjuvant use of vitamin D and calcium. The aim of this review is to study whether vitamin K2 could be of use to the actual treatment schemes as it is directly implicated in the normal metabolism of bone tissue. After consulting the current literature, we have found that vitamin $K 2$ is able to reduce the risk of fracture in osteoporotic patients, increase osteocalcin and diminish levels of undercarboxylated osteocalcin. In conclusion, vitamin $K 2$ has the capability of improving the outcome and evolution of osteoporosis with minimal to no adverse effects and possibly achieving higher treatment compliance.
\end{abstract}

\section{INTRODUCTION}

Osteoporosis (OP) is defined as a systemic skeletal disease due to loss of bone mineral density (BMD). Microarchitecture of the bone is also affected, leading to higher fragility and consequently increased risk of fractures.(1) In Europe, actual treatment options for OP include selective estrogen receptor modulators, bisphosphonates, peptides of the parathyroid hormone family and denosumab (monoclonal antibody against RANKL). Hormonal replacement therapy after the onset of menopause and vitamin $\mathrm{D}$ with calcium are also used to alleviate consequences of OP.(2)

A possible treatment option could be represented by vitamin $\mathrm{K} 2$ (VK) because of its several roles in bone metabolism. It works by stimulating osteoblastogenesis and inhibiting the formation of osteoclasts. In presence of $\mathrm{VK}$, osteocalcin (OC) is undergoing gamma carboxylation followed by a reduction of undercarboxylated osteocalcin(ucOC) level, thus improving bone calcification and alleviating healing of fractures. VK insufficiency is considered a risk factor for OP and $\mathrm{OP}$ fractures. $(3,4)$

Synthesis of OC is highly dependent on vitamin D3 (calcitriol), but OC can bind to hydroxyapatite in the bone tissue only in the carboxilated form. Therefore, vitamin $\mathrm{K}$ promotes mineralization of the bone. $(5,6)$

\section{AIM}

The aim of this review is to present the effects of VK alone or in combination with other accepted treatments of OP on $\mathrm{BMD}$, risk of fractures (RF) and its way of action on OC levels.

\section{MATERIALS AND METHODS}

Data Sources and Study Selection

We performed a MEDLINE search using the following terms: "osteoporosis treatment", "osteoporosis vitamin K", "osteoporosis menatetrenone" having applied the following filters: Clinical Study, Clinical Trial, Comparative Study, Controlled Clinical Trial, Randomized Controlled Trial.
Articles ranging from 1995 till 2020 were found, but only thosde published in English were taken into consideration. A possible limitation of the search process might include using only one website (PubMed) for article selection.

\section{Inclusion and exclusion criteria}

All the articles found were manually reviewed and selected based on the presence of the osteoporosis diagnosis of the patients and inclusion of VK in the treatments studied. A total of 10 articles were chosen to be presented. In all the sorted studies VK was administered in form of menatetrenone, $45 \mathrm{mg} /$ day.

\section{RESULTS}

Numerous studies have compared the efficacy of VK in increasing BMD and reducing the risk of fractures. A randomized open label study assessed the impact of daily administration of VK on BMD and incidence of OP fractures, over a period of 24 months. BMD declined with $-0.5 \% \pm 1.0 \%$ $\left(0.735 \pm 0.016 \% \mathrm{~g} / \mathrm{cm}^{2}\right)$, showing a better outcome then the control group (which received no treatment). Declined RF was observed despite the lowered BMD, also serum levels of OC were significantly raised by VK with $42.4 \pm 6.9 \%$ compared to baseline values.(7) Further studies have confirmed these findings. Iwamoto at al. have tested VK against etidronate (first generation bisphosphonate) and calcium over a period of 2 years. BMD was efficiently increased only by etidronate. RF has been proved to be lowered by $\mathrm{VK}$ with $65.2 \%$, also by etidronate. VK did not register a better outcome than etidronate, only than calcium.(8)

In relation with other types of treatments, Ishida et al. published a study in 2004 in which they compared VK to hormonal therapy, bisphosphonates, calcitonin, vitamin D and a control group, for a period of 2 years. VK registered a decrease of $-1.9 \%$ in BMD, which in comparison to the control group ($3.3 \%)$ showed significance at delaying loss of density $(\mathrm{P}=0.03)$. Relative risk of new vertebral fractures, in the VK group compared to control, was 0.44 (95\% CI: 0.20 to 0.99 ) which

${ }^{1}$ Corresponding author: Corina Adelina Zah, Str. Louis Pasteur, Nr.4, Cluj-Napoca, România, E-mail:corinazah@icloud.com, Phone: +40374834114 Article received on 15.04.2020 and accepted for publication on 28.05.2020 


\section{CLINICAL ASPECTS}

reached significance. Even with this data, VK did not achieve better results than the other treatments, except for raising serum levels of OC.(9)

Third generation bisphosphonates (risedronate or minodronate) were also tested in monotherapy versus in combination with VK. Results found no significant changes in incidence of fractures or BMD between the 2 groups. The only difference noted was the decrease in the serum levels of ucOC and maintenance of higher OC levels in the VK groups, fact that was pointed in most studies. $(4,10,11) \mathrm{VK}$ alone can decrease serum ucOC in short periods of time (less than 6 months). It was also remarked to provoke an increase in levels of OC containing gamma-carboxylated glutamic acid, intact levels of OC and urinary excretion of N-telopeptide of type 1 collagen (a marker of bone resorbtion).(12,13)

A finding that could be of interest is the significant decrease of the FR in a subgroup of patients with severe OP (at least 5 OP fractures at the time of study enrolment) that underwent treatment of $\mathrm{VK}$ and calcium (oral calcium Laspartate $1.2 \mathrm{~g} /$ day or dibasic calcium phosphate $3 \mathrm{~g}$ /day).(14)

This discovery could be expected in part because patients with severe OP and history of OP fractures tend to have a higher level of ucOC, thus by administering VK levels decrease leading to a lower risk.(11)

Another therapeutic scheme to be taken into consideration is combining VK with VD3. Menatretenone $45 \mathrm{mg}$ /day with $1 \alpha$ hydroxyvitamin $\mathrm{D} 3,0.75 \mu \mathrm{g}$ /day have been proved to increase $\mathrm{BMD}$ of the lumbar spine more than monotherapy of VK, VD or calcium.(6) A summarization of the studies presented can be found in table no. 1 .

\section{DISCUSSIONS}

Based on the results found, VK (menatetrenone) could be prescribed in osteoporotic patients for decreasing RF. Patient's therapeutic scheme should be consulted before, as VK is contraindicated in co-administration with warfarin. Adverse effects of VK were not reported in any significant manner, in comparison with the other pharmaceutical drug classes used for OP. This could be of major advantage, as introducing VK into the therapeutic scheme may be able to reduce the dose of other drugs and consequently limit the adverse effects. The outcome may result in better treatment compliance and an increase in quality of life.

Another potential use of VK could be together with VD3 and calcium for patients who are not under treatment with other classes of drugs. This combination might also be effective in preventing or delaying the onset of OP in women with multiple risk factors.

\section{CONCLUSIONS}

The mechanism of reducing RF, but not improving BMD is not understood and further research should be performed in this direction. As far as data shows, VK has the ability to improve the evolution of OP and diminish additional risks as OP fractures.

Table no. 1. Summarization of the studies presented and their findings

\begin{tabular}{|c|c|c|c|}
\hline Study (year) & $\begin{array}{l}\text { Groups of patients } \\
\text { (based on treatment) }\end{array}$ & BMD & Risk of fracture \\
\hline $\begin{array}{l}\text { Iwamoto et al. } \\
(2000)(6)\end{array}$ & $\begin{array}{l}\text { VD3 } \\
\text { VK } \\
\text { VD3+VK } \\
\text { Calcium } \\
24 \text { months period }\end{array}$ & $\begin{array}{l}\text { VD3 }+ \text { VK registered the best outcome } \\
\mathrm{P}<0.01 \text { vs VK } \\
\mathrm{P}<0.05 \text { vs VD3 } \\
\mathrm{P}<0.0001 \text { vs calcium }\end{array}$ & - \\
\hline $\begin{array}{l}\text { Shiraki et al. } \\
(2000)(7)\end{array}$ & $\begin{array}{l}\text { Control (no treatment) } \\
\text { VK } \\
24 \text { months period }\end{array}$ & $\begin{array}{l}\text { Not improved by VK. } \\
\text { Control performed worse. } \\
\text { Difference between groups at } 24 \text { months } \\
\mathrm{P}=0.0339\end{array}$ & $\begin{array}{l}\text { Significantly lower in the VK } \\
\text { group } \\
\mathrm{P}=0.0273\end{array}$ \\
\hline $\begin{array}{l}\text { Iwamoto et al. } \\
(2001)(8)\end{array}$ & $\begin{array}{l}\text { Control (calcium) } \\
\text { Etidronate } \\
\text { VK } \\
24 \text { months period }\end{array}$ & $\begin{array}{l}\text { Etidronate had the best outcome } \mathrm{P}<0.0001 \text { vs } \\
\text { calcium } \\
\mathrm{P}<0.01 \text { versus VK }\end{array}$ & $\begin{array}{l}\text { No difference between } \mathrm{VK} \text { and } \\
\text { Etidronate. Both overcame } \\
\text { calcium }\end{array}$ \\
\hline $\begin{array}{l}\text { Ishida et al. } \\
(2004)(9)\end{array}$ & $\begin{array}{l}\text { Control (no treatment) } \\
\text { Hormone replacement therapy } \\
\text { Etidronate } \\
\text { Calcitonin } \\
\text { VD } \\
\text { VK } \\
24 \text { months period }\end{array}$ & $\begin{array}{l}\text { VK was overcome by the other treatments, } \\
\text { except control }\end{array}$ & $\begin{array}{l}\text { VK did not perform better than } \\
\text { the other groups }\end{array}$ \\
\hline $\begin{array}{l}\text { Inoue et al. } \\
(2009)(14)\end{array}$ & $\begin{array}{l}\text { Calcium } \\
\text { Calcium }+ \text { VK } \\
36 \text { months period }\end{array}$ & - & Significance not obtained. \\
\hline $\begin{array}{l}\text { Kasukawa et al. } \\
(2014)(10)\end{array}$ & $\begin{array}{l}\text { Risedronate } \\
\text { Risedronate }+\mathrm{VK} \\
12 \text { months period }\end{array}$ & No difference between groups & No difference between groups \\
\hline $\begin{array}{l}\text { Ebina et al. } \\
(2016)(4)\end{array}$ & $\begin{array}{l}\text { Minodronate } \\
\text { Minodronate+VK } \\
\text { Minodronate+VD } \\
12 \text { months period }\end{array}$ & $\begin{array}{l}\text { Minodronate }+ \text { VD surpassed the other groups } \\
\mathrm{P}=0.0002 \text { vs monotherapy } \\
\mathrm{P}=0.03 \text { vs }+\mathrm{VK} * \text { lumbar spine }\end{array}$ & - \\
\hline $\begin{array}{l}\text { Tanaka et al. } \\
\text { (2017) (11) }\end{array}$ & $\begin{array}{l}\text { Risedronate } \\
\text { Risedronate }+\mathrm{VK} \\
24 \text { months period }\end{array}$ & $\begin{array}{l}\text { No difference between groups } \\
\mathrm{P}=0.62\end{array}$ & $\begin{array}{l}\text { No difference between groups } \\
\mathrm{P}=0.21\end{array}$ \\
\hline
\end{tabular}




\section{REFERENCES}

1. Consensus development conference: Diagnosis, prophylaxis, and treatment of osteoporosis, The American Journal of Medicine. 1993;94(6):646-650.

2. Kanis JA, Cooper C, Rizzoli R, Reginster JY. Executive summary of the European guidance for the diagnosis and management of osteoporosis in postmenopausal women. Calcif Tissue Int. 2019;104(3):235-8.

3. Butler L. March 19, 1960 NATURE. 1960;17(4716):4716.

4. Ebina K, Noguchi T, Hirao M, Kaneshiro S, Tsukamoto Y, Yoshikawa H. Comparison of the effects of 12 months of monthly minodronate monotherapy and monthly minodronate combination therapy with vitamin K2 or eldecalcitol in patients with primary osteoporosis. J Bone Miner Metab. 2016;34(3):243-50.

5. Douglas AS, Robins SP, Hutchison JD, Porter RW, Stewart A, Reid DM. Carboxylation of osteocalcin in postmenopausal osteoporotic women following vitamin $\mathrm{K}$ and D supplementation. Bone. 1995;17(1):15-20.

6. Iwamoto J, Takeda T, Ichimura S. Effect of combined administration of vitamin D3 and vitamin $\mathrm{K} 2$ on bone mineral density of the lumbar spine in postmenopausal women with osteoporosis. J Orthop Sci. 2000;5(6):546-51.

7. Shiraki M, Shiraki Y, Aoki C, Miura M. Vitamin K2 (Menatetrenone) Effectively Prevents Fractures and Sustains Lumbar Bone Mineral Density in Osteoporosis. J Bone Miner Res. 2010;15(3):515-21.

8. Iwamoto J, Takeda T, Ichimura S. Effect of menatetrenone on bone mineral density and incidence of vertebral fractures in postmenopausal women with osteoporosis: A comparison with the effect of etidronate. J Orthop Sci. 2001;6(6):487-92.

9. Ishida Y, Kawai S. Comparative efficacy of hormone replacement therapy, etidronate, calcitonin, alfacalcidol, and vitamin $\mathrm{K}$ in postmenopausal women with osteoporosis: The Yamaguchi Osteoporosis Prevention Study. Am J Med. 2004;117(8):549-55.

10. Tanaka S, Miyazaki T, Uemura Y, Miyakawa N, Gorai I, Nakamura $\mathrm{T}$, et al. Comparison of concurrent treatment with vitamin $\mathrm{K} 2$ and risedronate compared with treatment with risedronate alone in patients with osteoporosis: Japanese Osteoporosis Intervention Trial-03. J Bone Miner Metab. 2017;35(4):385-95.

11. Kasukawa Y, Miyakoshi N, Ebina T, Aizawa T, Hongo M, Nozaka K, et al. Effects of risedronate alone or combined with vitamin K2on serum undercarboxylated osteocalcin and osteocalcin levels in postmenopausal osteoporosis. J Bone Miner Metab. 2014;32(3):290-7.

12. Miki T, Nakatsuka K, Naka H, Kitatani K, Saito S, Masaki $\mathrm{H}$, et al. Vitamin $\mathrm{K} 2$ (menaquinone 4) reduces serum undercarboxylated osteocalcin level as early as 2 weeks in elderly women with established osteoporosis. J Bone Miner Metab. 2003;21(3):161-5.

13. Shiraki M, Itabashi A. Short-term menatetrenone therapy increases gamma-carboxylation of osteocalcin with a moderate increase of bone turnover in postmenopausal osteoporosis: A randomized prospective study. J Bone Miner Metab. 2009;27(3):333-40.

14. Inoue $T$, Fujita $T$, Kishimoto $H$, Makino $T$, Nakamura $T$, Nakamura $\mathrm{T}$, et al. Randomized controlled study on the prevention of osteoporotic fractures (OF study): A phase IV clinical study of $15-\mathrm{mg}$ menatetrenone capsules. J Bone Miner Metab. 2009;27(1):66-75. 